\title{
Obesity and the levels of liver enzymes (ALT, AST \& GGT) in East Medinipur, India
}

\author{
Ajay Kumar Das ${ }^{1}$, Prasanna Chandra ${ }^{2}$, Akash Gupta ${ }^{3}$, Naved Ahmad ${ }^{4}$ \\ ${ }^{1}$ Assistant Professor, Department of Biochemistry, ICARE Institute of Medical Sciences and Research, Haldia, East Medinipur, W.B. India, ${ }^{2}$ Assistant \\ Professor, Department of Biochemistry, College of Medicine, Jazan University, Jazan, KSA, ${ }^{3}$ Assistant Professor, Department of Biochemistry, Rama \\ Medical College and Hospital, Pilakhua, Hapur, U.P. India, ${ }^{4}$ PhD Scholar, Department of Biochemistry, Subharti Medical College Meerut, U.P. India
}

\section{A B S TR A C T}

Objective Obesity is a common disorder in our country. Most widely used method to gauge obesity is Body Mass Index (BMI) which is equal to weight in kilogram divided by height in meter square. The objective of our study was to find the levels of liver enzymes ALT, AST \& GGT in two groups (overweight individuals and obese individuals). Methods: A total no of 156 individuals were selected for the study and they were categorized into three groups on the basis of BMI- Group I Normal, BMI 18.5 to $24.9(n=72)$, Group II Overweight, BMI 25.0 to $29.9(n=39)$ and Group III Obese, BMI $>30(n=45)$. Serum ALT, AST \& GGT were estimated by Accurex AC 112 plus semi auto analyser and values were given in U/L. Results: Values of ALT, AST \& GGT were with in the normal references range in all the three groups. Conclusion: No significant relation was found between ALT, AST \& GGT in normal, overweight and obese individuals.

Key words: Obesity, ALT, AST, GGT

\section{INTRODUCTION}

Obesity is a common disorder in our country. It is proven predisposing factor of increasing morbidity and mortality in cardiovascular and neurovascular disease. ${ }^{1,2}$ Obesity is a state of excess adipose tissue mass. In presence of nutritional abundance (excess energy intake), sedentary life style and influence importantly by genetic endowment, endocrine and neuronal system increases adipose energy store and produces adverse health consequences. ${ }^{3}$ Most widely used method to gauge obesity is Body Mass Index (BMI) which is equal to weight in kilogram divided by height in metre square (Table 1). ${ }^{3,4}$

Aminotransferases ${ }^{5,6}$ are group of liver enzymes that catalyse inter conversion of amino acid to 2 - oxoacid by transfer of aminogroup. These include alanine amino transferase (ALT enzyme commission no- 2.6.1.2) and aspartate amino transferase (AST enzyme commission no- 2.6.1.1). Gamma glutamyl transferase (GGT enzyme commission no- 2.3.2.2) is a peptidase enzyme present in liver, which catalyze hydrolytic cleavage of peptide to form amino acid or small peptides. It catalyzes the transfer of gamma glutamyl moiety of glutathione to acceptor that may be an amino acid.?

Regional body fat distribution, with abdominal fat accumulation may represent a strong predictor of elevated liver enzymes (ALT, AST \& GGT) then relative weight as assessed by BMI. ${ }^{8,9}$ Many studies have found increased levels of ALT, AST \& GGT due to alcohol, hypertension and fatty liver. ${ }^{9-11}$ Very less studies have been done in this part of our country to find out direct relation between obesity and levels of liver enzymes. The objective of the study was to find association between levels of liver enzymes in overweight and obese individuals grouped on the basis of BMI cut off.

\section{MATERIALS AND METHODS}

The present hospital based study was undertaken in the Department of Biochemistry in collaboration with the Department of Medicine of Dr BC Roy hospital, attached 
with ICARE Institute of Medical Sciences and Research. The present study was conducted from Oct 2013 to Jan 2014, after obtaining ethical clearance from the institute. A total of 156 healthy individuals belonging to age group $30-70$ years from both sexes $($ Males $=74$ and Females $=82)$, who visited for routine health screening, were selected from Medicine O.P.D. Height and Weight of all the individuals were measured. These healthy individuals were divided into three groups according to their BMI4. Group I - Normal (BMI 18.5 to 24.9), Group II - Overweight (BMI 25.0 to 29.9) and Group III - Obese (BMI > 30).

Patients having diabetes, acute or chronic liver disease, renal, cardiovascular or respiratory disease, alcoholics, patients on any medicine which can increase liver enzymes, were not included in study. Serum ALT, AST \& GGT enzymes levels of these patients were estimated on Accurex AC 112 plus semi auto analyser from Accurex Biomedical India.

\section{Statistical analysis}

Data was analysed by unpaired student $t$ test. Results were expressed as mean \pm standard deviation.

\section{RESULTS}

In our study the individuals were divided into three groups on the basis of BMI. Total no of individuals in Group I were 72 (38 males \& 34 females), in Group II were 39 ( 17 males \& 22 females) and in Group III were 45 (19 males \& 26 females). From our study it was seen that the number of females were more as compared to males in Group II and III (Table 2).

In all the three group values of ALT, AST \& GGT were within the normal reference range (Table 3). However there was an increase trend in the values from normal to obese. No significant relation was found between ALT, AST \& GGT and obesity as the p value was $>0.01$ when compared between Group II and Group III (Table 3).

\section{DISCUSSION}

In our present hospital based study we estimated the values of liver enzymes (ALT, AST \& GGT) in individuals who were divided into normal, overweight and obese on the basis of BMI. Levels of liver enzymes were not significant statistically when compared between group II and III as the $\mathrm{p}$ value was $>0.01$.

Rhul CE et $\mathrm{al}^{8}$ in their study found that the proportion of elevated ALT activity due to overweight and obesity (BMI $\geq 25 \mathrm{~kg} / \mathrm{m}^{2}$ ) was $65 \%$. ALT activity was most

\begin{tabular}{lcl}
\multicolumn{3}{l}{ Table 1: Classification of weight status and risk } \\
of disease is given as follows
\end{tabular}

\begin{tabular}{|c|c|c|c|}
\hline & Group I & Group II & Group III \\
\hline Males & 38 (24.3\%) & $17(4.4 \%)$ & $19(12.1 \%)$ \\
\hline Females & $34(21.7 \%)$ & $22(14.1 \%)$ & $26(16.6 \%)$ \\
\hline
\end{tabular}

\begin{tabular}{|c|c|c|c|c|}
\hline & $\begin{array}{l}\text { Group I } \\
\text { Normal } \\
(n=72)\end{array}$ & $\begin{array}{l}\text { Group II } \\
\text { Overweight } \\
(n=39)\end{array}$ & $\begin{array}{c}\text { Group III } \\
\text { Obese } \\
(n=45)\end{array}$ & $p$ value \\
\hline $\begin{array}{l}\text { ALT (In U/L) } \\
\text { Mean } \pm S D\end{array}$ & $24.72 \pm 2.31$ & $270.81 \pm 3.12$ & $31.96 \pm 3.53$ & 0.21 \\
\hline $\begin{array}{l}\text { AST (In U/L) } \\
\text { Mean } \pm S D\end{array}$ & $30.22 \pm 2.85$ & $33.54 \pm 2.97$ & $35.72 \pm 3.71$ & 0.28 \\
\hline $\begin{array}{l}\text { GGT (In U/L) } \\
\text { Mean } \pm S D\end{array}$ & $28.34 \pm 2.09$ & $29.6 \pm 3.42$ & $32.41 \pm 2.26$ & 0.19 \\
\hline
\end{tabular}

strongly associated with higher WHR where as BMI was not independently related. Stranges $S$ et $\mathrm{al}^{9}$ evaluated the relation between central fat accumulations, as assessed by BMI and liver function tests (ALT, AST \& GGT). Abdominal height was consistently a better correlate of ALT \& GGT levels than BMI in both sexes. Their findings supported a role for central adiposity independent from BMI in predicting increased levels of hepatic enzymes, likely as a result of unrecognized fatty liver.

Marchesini $G$ et $a^{12}$ analysed alanine and aspartate aminotransferases (ALT \& AST) and gamma-glutamyl transpeptidase (GGT) in a group of treatment - seeking obese patients. Median ALT \& AST increased with increasing obesity class $(\mathrm{p}=0.001$ and $\mathrm{p}=0.005)$ and exceeded normal limits in $21.0 \%$ of cases. Also HOMA-IR increased with the obesity class $(\mathrm{p}<0.0001)$ and was higher in subjects with elevated ALT ( $p<0.0001)$.

In a study done by Strauss RS et $\mathrm{al}^{13}$ sixty percents of adolescents with elevated ALT levels were either overweight or obese. In addition, approximately 1\% obese adolescents demonstrated ALT levels over twice normal. Approximately $50 \%$ of obese adolescents who reported modest alcohol ingestion (four times per month or more) had elevated ALT levels. Choi JW ${ }^{14}$ found that mean activities $( \pm S D)$ of serum ALT and 
AST in men with high fatness were significantly higher than those in men with low fatness $(p<0.01)$. Out of 147 men with high fatness, 56 (38.1\%) had serum ALT levels above the upper limit of normal, where as only $9.5 \%(31 / 328)$ of men with low or desirable fatness showed elevated serum ALT activities $(\mathrm{p}<0.01)$. serum ALT, AST \& GGT activities correlated significantly with total body fat (TBF) in both over weight men and women. Sull JW et a $1^{15}$ found that across the range of BMI values $\left(<18.5\right.$ to $\left.\geq 32 \mathrm{~kg} / \mathrm{m}^{2}\right)$ in man, alanine amino transferase (ALT) was estimated to increase by $18.8 \mathrm{U} / \mathrm{L}$ and aspartate amino transferase (AST) increased by $7.1 \mathrm{U} / \mathrm{L}$. In men, interactions between BMI and alcohol consumption were significant $(p<0.001)$ for ALT\& AST, but the degree of effect modification was quantitatively minor. For women relationship of amino transferase levels with BMI did not vary by alcohol consumption.

Adams LA et $\mathrm{al}^{16}$ in their study found that the majority of the subjects were either overweight $(41 \%)$ or obese $(17 \%)$. A minority of subjects were moderate $(25 \%)$ or heavy drinkers (4\%). BMI and waist circumference were strongly associated with ALT and GGT ( $p<0.0001$ for all test). The risk of an elevated ALT was seven fold higher with obesity but only two fold higher with moderate or heavy alcohol use. Obesity accounted for half of all elevated levels in the cohort, where as alcohol excess was responsible for less than $10 \%$.

\section{CONCLUSION}

In all the above mentioned studies patients were either alcoholics, smokers, hypertensive or having fatty liver which was the cause of elevated liver enzymes, while in our study no such factor was taken into consideration. This could be one of the causes for normal levels of liver enzymes in the normal, overweight and obese individuals of our study. Till date studies have provided contrast findings. In order to understand complex interaction between liver enzymes and obesity there is a need for study on larger cross section of the population to elucidate the association.

\section{ACKNOWLEDGEMENT}

The study was self funded and there was no conflict of interest among the authors.

\section{REFERENCES}

1. Shaper AG, Pocock SJ, Ashby D, Walker M and Whitehead TP. Biochemical and haematological response to alcohol intake. Ann Clin Biochem 1985; 22(Pt1):50-61.

2. Sillanaukee $P$, Massot $N$, Jousilathi $P$, Vartiainen $E$, Sundevall J, Olsson U, et al. Dose response of laboratory markers to alcohol consumption in general population. Am J Epidemio 2000; 152(8):747-751.

3. Kasper DL, Braunwald E, Fauci AS, Hauser SL, Longo DL, Jameson JL and Loscalzo J. Harrison's Principles of internal medicine. $17^{\text {th }}$ ed. New York: McGraw-Hill; 2008. vol 2 p1549-1562.

4. Clinical Guidelines on Identification, Evaluation and Treatment of Overweight and Obesity in Adults. The Evidence Report. NIH Publication. 1998. Report No 98-4083.

5. Burtis CA, Ashwood ER, Bruns DE. Teitz Textbook of Clinical Chemistry and Molecular Diagnostics. 4th ed. St Louis: Elsevier Saunders; 2006. p 604-612.

6. Dufour DR, Lott JA, Nolte FS, Gretch DR, Koff RS, Seeff LB, et al. Diagnosis and monitoring of hepatic injury. I. Performance characteristics of laboratory test. Clin Chem 2000; 46(12):2027-2049.

7. Whitefield JB. Gamma glutamyl transferase. Crit Rev Clin Lab Sci 2001; 38(4):263-355.

8. Ruhl CE and Everhart JE. Determinant of the association of overweight with elevated serum alanine aminotransferase activity in United States. Gastroenterolgy 2003;124(1):71-79.

9. Stranges S, Dorn JM, Muti P, Freudenheim JL, Farinaro E, Russell $M$, et al. Body fat distribution, relative weight and liver enzymes levels: A population based study. Hepatology 2004;39 (3):754-763.

10. Stranges S, Trevisan M, Dorn JM, Dmochowski J and Donahue RP. Body fat distribution, liver enzymes and risk of hypertension: evidence from the western New York study. Hypertension 2005; 46(5):1186-1193.

11. Gupta A, Panthari M, Ahmad N, Nagtilak S and Nandwani S. Levels of alanine aminotransferase (ALT), aspartate aminotransferase (AST) and gamma glutamyl transferase (GGT) in hypertension. Biomed Res-India 2012; 24(1):59-61.

12. Marchesini G, Avagnina S, Barantani EG, Ciccarone AM, Corica F, Dall'Aglio E, et al. Aminotransferase and Gamma glutamyl transpeptidase levels in obesity are associated with insulin resistance and the metabolic syndrome. J Endocrinol Invest 2005; 28(6):333-339.

13. Strauss RS, Barlow SE and Dietz WH. Prevalance of abnormal serum transferase values in overweight and obese adolescents. J Pediatr 2000; 136(6):727-733.

14. Choi JW. Association between elevated serum hepatic enzyme activity and total body fat in obese humans. Ann Clin Lab Sci 2003;33(3):257-264.

15. Sull JW, Yun JE, Lee SY, Ohrr H, Jee SH, Guallar E, et al. Body mass index and serum aminotransferase levels in Korean men and women. J Clin Gastroenterol 2009; 43(9):869-875.

16. Adams LA, Knuiman MW, Divitini ML and Olynyk JK. Body mass index is a stronger predictor of alanine aminotransferase levels than alcohol consumption. J Gastroenterol Hepatol 2008; 23(7 Pt1):1089-1093.

\footnotetext{
Authors Contribution:

AKD - collected and compiled the data; PC - designed the concept of study; AG - proof reading, drafting and correspondence of the manuscript; NA - statistical analysis.

Source of Support: Nil, Conflict of Interest: None declared.
} 